VOX PATRUM 29 (2009) t. 53-54

\title{
Jan ILUK
}

(Gdańsk, UG)

\section{APISTIA NIE ROZRYWA MAŁŻEŃSTWA Jan Chryzostom o malżonku (-nce) spoza chrześcijańskiej politei}

Jan Chryzostom poza kilkoma traktatami o życiu kobiet w stanie pozamałżeńskim i krótkimi mowami o godności chrześcijańskiej kobiety, nie wdawał się w dłuższe dyskursy o małżeństwie. Jeśli już dotykał spraw rodziny, to $\mathrm{w}$ wypowiedziach o sposobie wychowania dzieci ${ }^{1}$. Stąd też przyjmijmy, że głębszych rozważań na temat stanu małżeńskiego na miarę przemyśleń studium o stanie duchownym, nie znajdziemy w jego przebogatej spuściźnie oratorsko-literackiej. Jednak w swoich homiliach i traktatach kilkanaście razy sięga po motyw niewierzacego (-ej) wspótmatżonka (-nki) ${ }^{2}$. Poznawszy te przypadki można nabrać przekonania, że również i one, na podobieństwo chociażby objaśnień zasad chrześcijańskiej ,,agape”3, miały za cel nie tyle ugodę rodzinną, co jedność rodzin żyjących we wspólnocie. Oczywiście, cel drugi

${ }^{1}$ Jana Chryzostoma i innych Ojców Kościoła wizję chrześcijańskiej rodziny omówiono w pracach zebranych w VoxP 5 (1985) z. 8-9, tam też (s. 443-507) literatura powszechna zestawiona przez S. Longosza; zob. ponadto: S. Longosz, Rodzina wczesnochrześcijańska i jej zadania w nauczaniu św. Bazylego Wielkiego, RTK 28 (1981) 149-168; J. Iluk, Chrześcijańskie matżeństwo i rodzina w rzymskiej starożytności, w: Małżeństwo $w$ dawnym judaizmie i starożytnym chrześcijaństwie, red. W. Pałubicki - J. Iluk, Gdańsk 1995, 151-331.

${ }^{2}$ „Apistos” (ő $\left.\pi 1 \sigma \tau o \varsigma\right)$ - niewierzący, niedowiarek - stał się w epoce rzymskiego prawa poklasycznego jednym z wyznaczników prawości związku małżeńskiego. W środowisku chrześcijańskim eufemizm „apistos” nie odnosił się do wybranego środowiska. Jeżeli pojawiał się w wypowiedzi osoby z kręgu nicejskiego Kościoła, wówczas mógł wskazywać na heretyka, apostatę, schizmatyka, Hellena - wyznawcę kultu hellenistycznego, poganina lub Żyda. W ustawach cesarskich (XVI Księga Kodeksu Teodozjusza), kanonach synodalnych i w nauczaniu Ojców Kościoła, kręgi niewierzących nachodzą na siebie, ale żadną miarą nie można ich objąć jednym określeniem poganie. W pismach autorów chrześcijańskich doby antycznej „niewierzący” stał się synonimem nie-chrześcijanina. Jan Chryzostom w swoich wypowiedziach na temat niewierzących, jeśli nie było merytorycznej potrzeby, aby użyć nazwy własnej dla religii, kultu lub sekty, używał trzech wyróżników: poganin, Hellen lub Żyd.

${ }^{3}$ Por. J. Iluk, Jan Chryzostom objaśnia Hymn o miłości (In I epistolam ad Corinthios hom. 33-34), w: Księga Jubileuszowa Księdza Profesora Stanisława Longosza = VoxP 28 (2008) t. 52/1, 291-315; tenże, Miłość (agápe) w nauczaniu Jana Chryzostoma (Późnoantyczna pragmatyka 
jest w dużej mierze pochodną osiągnięcia celu pierwszego - familia seminarium rei publicae est ${ }^{4}$. Dla Chryzostoma była to przede wszystkim dobra okazja, aby problem obecności niewierzącego w chrześcijańskiej rodzinie rozwiązać, kierując się dobrem politei. Jak tę okazję Jan Chryzostom wykorzystał, o tym kilka uwag chciałbym zamieścić w tym tekście.

O współmałżonku (-nce) spoza kręgu chrześcijańskiego, Jan Chryzostom najszerzej wypowiedział się, kiedy komentując I List do Koryntian, doszedł w XIX homilii do siódmego rozdziału tego Listu i rozpoczął objaśnianie privilegium Paulinum. Przedstawione tam przyzwolenia i zakazy, co do okoliczności rozerwania związku małżeńskiego, a także przejęcie przez św. Pawła funkcji ustawodawcy (,Ja mówię, nie Pan”), zawsze zmuszają do bardziej uważnego śledzenia słów apostolskiego przesłania do Koryntian. Trzeba przyznać, że ten passus Listu w poważnym stopniu pogłębia chrześcijańską tajemnice współżycia kobiety i mężczyzny, współżycia zwanego matrimonium. Choćby tylko przy tej okazji, warto przypomnieć późniejsze stwierdzenie Augustyna, jakie wyraził w swym traktacie Cudzołożne małzeństwa, przy okazji rozmowy o małżeństwach mieszanych:

„Po dokładnym omówieniu tych spraw, według moich możliwości, wiem dobrze, że zagadnienie dotyczące małżeństw jest bardzo niejasne i zawikłane. I nie mam odwagi twierdzić, że wyjaśniłem dotąd wszystkie jego niejasności, albo w tym dziele, albo w innym, albo że już mogę wyjaśniać, gdybym był przynaglony"5.

Jak ową niejasność w kwestii współżycia z niewierzącym pojmował antiocheński kapłan i jakie proponował jej rozwiązanie na przełomie 390/391 roku? Przypomnę dialog, jaki wtedy z potrzeby objaśnienia tekstu 1 Kor 7, 12-13 Chryzostom wprowadził do XIX homilii komentarza:

chrześcijańskiego życia), w: Miłość w czasach dawnych, red. B. Możejko - A. Paner, Gdańsk 2009, 17-40.

${ }^{4}$ Por. Cicero, De officiis I 17.

${ }^{5}$ De coniugiis adulterinis I 25, 32, PL 40, 459, thum. M. Damian, w: Pisma świętego Augustyna o malżeństwie i dziewictwie, red. A. Eckmann, Lublin 2003, 256-257. Rozterki Augustyna co do korzystania z ex privilegio Paulino, aby rozwieść się z niechrześcijaninem (-ką), po części wynikały $\mathrm{z}$ tego, że dla niego brak wiary (infidelitas) zasługiwał na miano „duchowego cudzołóstwa”. Wychodząc z takiej oceny bycia niewierzącym (niechrześcijaninem) Augustyn oświadcza (De coniugiis adulterinis I 18, 20: „Jeżeli tylko jedno z małżonków uwierzyło... nie powinno być zakazu opuszczenia niewierzącego. Zakazu nie powinno być dlatego, ponieważ sprawiedliwość zezwala odejść od popełniającego cudzołóstwo, a cudzołóstwo popełnione przez niewierzącego człowieka w sercu jest większe i jego czyste współżycie z żoną nie może być nazwane prawdziwym, ponieważ: «Wszystko co nie jest z wiary, jest grzechem» (Rz 14, 23)".

${ }^{6}$ Por. 1Kor 7, 12-13: „Pozostałym zaś mówię ja, nie Pan: Jeśli któryś z braci ma żonę niewierzącą i ta chce razem z nim mieszkać, niech jej nie oddala! Podobnie jeśli jakaś żona ma niewierzącego męża i ten chce razem z nią mieszkać, niech się z nim nie rozstaje!”. 
„Podobnie do dyskusji o oddaleniu cudzołożników, kiedy to [apostoł] swoje rozporządzenie uczynił lżejszym wprowadzając uzupełnienie: «Nie chodzi o rozpustników tego świata» (1Kor 5, 10), również tutaj troszczy się o to, aby jego nakaz był możliwy do spełnienia. Oświadcza więc: nie powinno dojść do rozwodu, jeżeli żona posiada niewierzącego męża, lub mąż posiada żonę niewierzącą. - Co ty mówisz? Niewierzący powinien pozostać z żoną, a cudzołożnik nie powinien? Czyż cudzołóstwo nie jest czymś błahym w porów-

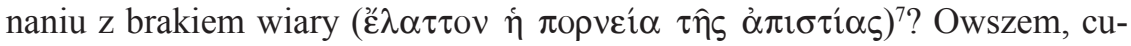
dzołóstwo jest mniej istotne, ale Bóg przede wszystkim troszczy się o twoje dobro. Dał temu świadectwo ustalając zasadę składania ofiary: «zostaw swój dar i pojednaj się z bratem swoim» (Mt 5, 24), a także wtedy gdy zaniechawszy ukarania dłużnika tysiąca talentów, ukarał tego, który zażądał 100 denarów od równego sobie poddanego. Powodowany troską o kobietę, która mogłaby się obawiać, że we współżyciu [z niechrześcijaninem] zostanie nieczystą, [Apostoł] uspokajająco dodaje: «Uświęca się bowiem mąż niewierzący dzięki żonie, podobnie jak dzięki mężowi uświęca się niewierząca żona» (1Kor 7, 14). - No dobrze, skoro jednak współżyjący z cudzołożnicą staje się z nią jednym ciałem, to czy nie jest także jednym ciałem współżyjąca z bałwochwalcą? To prawda, ona i on jest jednym ciałem, ale ona nie staje sie nieczystą. Czystość żony przezwycięża nieczystość męża, podobnie jak czystość wierzącego męża pokonuje nieczystość niewierzącej żony. - Dlaczego w tym przypadku nieczystość zostaje przezwyciężona i przyzwala sie na współżycie, a w przypadku cudzołóstwa żony, mężowi nie zabrania się jej oddalenia? Dlatego, że tutaj pojawia się nadzieja na pozyskanie przez malżeństwo brakującej części. Natomiast [cudzołóstwo] rozrywa małżeństwo i unicestwia obie strony. Tutaj tylko jedna strona jest winna; bałwochwalca jest nieczystym, ale żona nie jest nieczystą. Gdyby wspólnie z nim oddawałaby się bezbożności, byłaby nieczystą. Tym czasem żonę z mężem łączy małżeństwo i współżycie, a nie nieczyste zajęcia bałwochwalcy. Tutaj pojawia się więc nadzieja, że własna żona zmieni niewierzącego męża. Niemożliwe jest to tam [gdzie cudzołóstwo]. Czy żona, która pozbawiła męża godności, usługując innemu i łamiąc prawa małżeńskie, może zdradzonego uważać za swojego męża? Po cudzolóstwie mąż już nie jest mężem. Natomiast żona uprawiająca bałwochwalstwo nie narusza praw męża. Poza tym z niewierzącym żyje na jego życzenie, co zaznaczył [Apostoł] oświadczając: «a ten chce razem z nią mieszkać». Powiedz mi więc, czy jest jakieś zło w tym, że małżonkowie pozostaną w związku, który daje nadzieje na nawrócenie niewiernego i zapewnia bogobojność a także oddala niepotrzebne kłótnie? Powyższe uwagi [Apostoł] odnosi do zawartych małżeństw, a nie do planowanych związków małżeńskich. Nie powiedział: «Jeżeli ktoś zamierza zawrzeć mał-

${ }^{7}$ To znaczy: Czy cudzołóstwo nie jest zbyt małym przewinieniem aby z jego powodu doprowadzać małżeństwo do rozwodu? 
żeństwo z niewierzącym», ale: «jeśli ktoś ma niewierną». To znaczy, jeżeli po ożenku lub zamążpójściu, jedna ze stron przyjmie prawdziwą wiarę, a druga strona pozostanie w niedowiarstwie ( $\tau \hat{\jmath} \dot{\alpha} \pi \imath \tau \tau$ í $\alpha$ ), wówczas malżeństwo nie ulega rozwiązaniu. «Uświęca się bowiem mąż niewierzący dzięki swej żonie». Oto zysk ( $\pi \varepsilon p ı v \sigma i ́ \alpha)$ jaki daje twoja czystość. - Jak to, Hellen ma być świętym? Nie, Apostoł nie powiedział: «jest świętym», ale «uświęca się dzięki żonie». Nie stwierdził, że [Hellen] jest także świętym, ale chciał uspokoić kobietę, a w mężu rozbudzić pragnienie poznania prawdy. Nieczystość nie objawia się w jedności ciał, ale w samowoli i w zachciankach. Oto dowód: jeżeli, będąc nieczystą, urodzisz dziecko, które nie tylko od ciebie pochodzi, to czy ono jest nieczyste w całości, czy tylko w połowie? Oczywiście, nie jest nieczyste. «W przeciwnym wypadku», mówi Apostoł, «dzieci wasze byłyby nieczyste; a przecież teraz są świętymi» (1Kor 7, 14), to znaczy nie są nieczystymi. Nazywa je świętymi, aby tym mocnym stwierdzeniem odpędzić obawy małżonków"8.

Ta i kilkanaście innych wypowiedzi Chryzostoma, jakie odnalazłem w jego pismach, pozwalają sądzić, że jego ocena wartości związku wierzącej (-ego) z niewierzącym (-ącą) podyktowana jest realizmem epoki, a nie wyłącznie dogmatem. Nie chcę przez to powiedzieć, że jest wyższą od tej, jaką dają inni Ojcowie Kościoła, zwłaszcza - co ma swoją wymowę - Ojcowie z zachodniej części państwa rzymskiego, ale ma czytelne odniesienie do społecznego usytuowania Kościoła we wschodnich prowincjach państwa rzymskiego. W tym względzie jego poglądy odbiegają od surowych kanonów nauczania św. Bazylego z Kapadocji ${ }^{9}$. Przypomnę ocenę jego poglądów, jaką sformułował E. Przekop: „Sw. Bazyli nie odróżnia w swojej nauce o małżeństwach mieszanych przeszkód różności religii i odmiennego wyznania i obie stawia na tym samym poziomie. Nadto wszystkie przeszkody małżeńskie, jakie wylicza w swoich katalogu, św. Doktor uważa za rozrywające i nazywa je specjalnym terminem «fornicationes»" ${ }^{10}$. W Antiochii, tak surowa kwalifikacja tych związków, wzbudziłaby u wierzących i niewierzących co najmniej zdziwienie. Antiochia, w której Chryzostomowi przyszło rozpoczynać służbę kapłańską (386 r.), aż kipiała bujnym życiem najprzeróżniejszych wspólnot religijnych. Przedstawiciele tych wspólnot są adresatami kilku serii homilii Chryzostoma $^{11}$, lub pod mianem judaizantów, Hellenów i pogan, pojawiają się chyba w każdym kazaniu. Wszyscy oni byli najbliższymi sąsiadami antiocheńskich chrześcijan, więc kontakty z nimi dostarczały kapłanom, filozofom, pisarzom, a także i miejskim służbom, niejednej okazji do wypowiedzi i inter-

${ }^{8}$ In Epistolam I ad Corinthios hom. 19, 2-3, PG 61, 154-155.

${ }^{9}$ Por. Basilius, Epistola 199 (ad Amphilochium) can. 41, PG 32, 729.

${ }^{10}$ E. Przekop, Przeszkoda różności religii w kościele bizantyjskim, PK 14 (1971) z. 3-4, 43.

${ }^{11}$ Por. Adversus Judaeos orationes 1-8, PG 48, 843-942; Contra Judaeos et gentiles, PG 48, 813-838, wszystkie thum. J. Iluk, ŹMT 41, Kraków 2007; Contra Anomoeos, PG 48, 795-802. 
wencji. Bywało gorąco, czego dowodem jest fakt, że w 2. poł. IV wieku często miały tutaj miejsce wydarzenia zwane przez historyków „niepokojami na tle religijnym" 12 .

Zawołanie „tworzymy jedno ciało”, rozlegało się więc nierzadko wśród wielowyznaniowego społeczeństwa późnoantycznej Antiochii. Jan Chryzostom, zostając prezbiterem antiocheńskiego Kościoła, za jedno z głównych zadań swojej służby przyjął umacnianie jedności chrześcijańskiej politei. W mieście, liczącym wówczas ok 400 tysięcy mieszkańców, nie było to błahe zadanie. Jak sam szacował, chrześcijan, „którzy się tu gromadzą dochodzi do stu tysięcy”13, co według niego „stanowi większą część naszego miasta”14. Można być pewnym, że nie byli to wyłącznie ortodoksyjni „nicejczycy”. Jednak na odbycie triumfu było jeszcze za wcześnie. Redagując w 394 r. komentarz do I Listu św. Pawła do Tymoteusza, w gorzkich słowach opisał bliskie mu środowisko antiocheńskich chrześcijan:

„Nikt by nie pozostał Hellenem, gdybyśmy byli w pełni chrześcijanami. Nie znalazłby sie ani jeden szaleniec, który nie przyjąłby prawdziwej wiary, gdybyśmy przestrzegali przykazań Chrystusa, z pokorą znosili obrazę i gwałty, błogosławieństwem odpowiadali na nagany, a cierpiąc niedostatek rozdawali swoje majętności. O, gdyby w ten sposób wszyscy postępowali! Dam wam przykład. Paweł był sam, a iluż ludzi przyciągnął? Ileż światów (oiko-

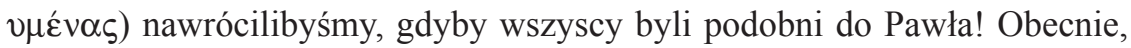
choć chrześcijan jest więcej aniżeli pogan, to niewielu do nas się dołącza. Jeden nauczyciel może uczyć i stu uczniów, a przecież mamy nauczycieli więcej niż uczniów. No cóż, uczniowie przyglądają się cnotom nauczycieli. I co widzą? To, że zabiegamy i pożądamy tego samego co oni, to znaczy, że także pragniemy chwały i władzy. Niby dlaczego więc poganie mieliby z szacunkiem odnosić się do chrześcijaństwa? Widzą zdeprawowane życie

${ }^{12}$ Por. J. Hahn, Gewalt und religiöser Konflikt, Berlin 2004, 121-190 (Antiochia). Tło i przebieg religijnych konfliktów znajdziemy także w pracy, która w tym roku ukazuje się nakładem Wydawnictwa Uniwersytetu Lódzkiego: P. Filipczak, Rozruchy i niepokoje w miastach bizantyjskich w IV wieku n.e., Łódź 2009.

${ }^{13}$ In Matthaeum hom. 80, 4, PG 58, 729; homilie komentujące Ewangelię św. Mateusza datowane są na 390 rok. Jak w wielu innych przypadkach przywołana liczba jest liczbą symboliczną (okrągłe sto tysięcy), chociaż można sądzić, że taki szacunek populacji chrześcijan w antiocheńskiej politei był przynajmniej akceptowanym przez jego słuchaczy. O symbolicznej wartości tego szacunku świadczy ponowne jego przywołanie, ale już w odniesieniu do Konstantynopola. Oto w późniejszej o 10 lat homilii na Dzieje Apostolskie (In Acta apostolorum hom. 11, 3, PG 60, 97) wołał: „Powiedzcie, proszę, ilu mieszkańców teraz liczy nasze miasto? Ilu w nim jest chrześcijan? Sądzicie, że 100 000, a pozostali to Hellenowie i Żydzi? Ile więc dziesiątek tysięcy sztuk złota zebranoby [gdyby każdy sprzedał swój majątek]? A jak wielu jest biedaków? Nie sądzę, aby było więcej niż 50 000. Ile mogłoby kosztować ich codzienne wyżywienie? Wspólne utrzymanie i wspólny stół zapewne nie wymagałby wielkich nakładów".

${ }^{14}$ Ad populum Antiochenum hom. 3, 1, PG 49, 47. 
i dusze przyziemne; widzą, że w podobnym stopniu, a może i bardziej niż oni, jesteśmy żądni pieniędzy; widzą jak drżymy przed śmiercią, jak na równi z nimi boimy się nędzy, narzekamy na cierpienia, kochamy władzę i siłę, a powodowani żądzą bogacenia się wyczekujemy dobrej okazji. Niby z jakiego więc powodu mieliby stać się wierzącymi? Z powodu cudów, których śladów nigdzie nie widać? Będziemy musieli odpowiedzieć za to, nie tylko spowiadając się z grzechów, ale i odpowiadając za zgubę innych. Opamiętajmy się! Bądźmy czujni! Dajmy tutaj, na ziemi, przykłady życia na wzór niebiańskiej politei! Mówiąc: «Nasza ojczyzna $(\pi \circ \lambda i ́ \tau \varepsilon v \mu \alpha)$ jest w niebie» (Flp 3, 20), stańmy do walki"15.

W wielokulturowym mieście, jakim była Antiochia nad Orontesem, w którym z autochtonami sąsiadowali przybysze z Europy, Afryki i Azji, małżeństwo mieszane nie mogło budzić zdziwienia. W rozumieniu klasycznego prawa rzymskiego, przeszkodą (impedimentum) na drodze do zawarcia małżeństwa mogła być bliskość pokrewieństwa (respectus parentalae) i pewne względy natury społecznej ${ }^{16}$, co oznacza, że przed epoką prawa justyniańskiego (poklasycznego), potępianie takich związków byłoby bezprawne ${ }^{17}$. W granicach chrześcijańskiej politei obraz ten zmienia się z początkiem IV wieku.

${ }^{15}$ In Epistolam I ad Timotheum hom. 10, 3, PG 62, 551-552.

${ }^{16}$ Pomiędzy senatorem i wyzwolennicą lub artystką; urzędnikiem cesarskim pełniącym funkcje w prowincji a kobietą urodzoną w tej prowincji; pomiędzy opiekunem i mu poddaną (tutor et pupilla); ze skazanym (- ną) za popełnione przestępstwo; z powodu służby wojskowej (matrimonium militis). Dopiero w „prawie justyniańskim” pojawia się impedimentum z tytułu poprzedniego ślubu (binae nuptiae) i wyznania religijnego (disparitas cultus).

${ }^{17}$ Jak Chryzostom odnosił się do norm prawa cywilnego, dobry przykład znajdujemy we fragmencie homilii na słowa 1 Kor 7, 2, por. In illud: „Propter fornicationes unusquisque uxorem ha-

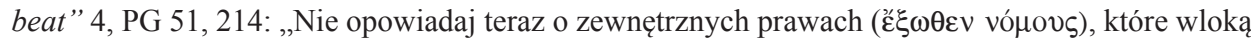
cudzołożne kobiety do sądów i stawiają je pod oskarżeniem, a ożenionego mężczyznę, oddającego

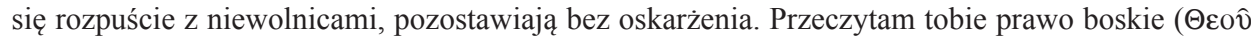
vó $\mu$ ov), które w jednaki sposób gani kobietę i mężczyznę, a taki czyn nazywa cudzołóstwem ( $\mu$ or $\chi \varepsilon$ í $\alpha v)$. Apostoł powiedziawszy: «Niech każda żona ma swego męża», dodał: «mąż niech żonie powinną wdzięczność ( $\varepsilon u ̛ v o r \alpha v)$ oddaje». Cóż chciał wyrazić tymi słowami? Czyżby to, aby mąż oszczędzał jej pieniężne dochody, aby zachował w całości posag, aby stroił ją w drogie suknie? A może ma na myśli wystawne uczty, olśniewające podróże, lub powiększanie zastępów sług? Czyżby to wszystko razem wzięte miało być oznaką miłości? Powiedz, w jakiej postaci oczekujesz odwzajemnienia się ( $v_{v}(\alpha)$ ) ? Nie, oświadcza Apostoł, nic podobnego nie mam na myśli. Mowie o cnotliwym zachowaniu i czystości. Ciało męża nie należy już do niego, ale do żony. Niech więc zachowa w całości własność przynależną żonie. Niech tej własności nie umniejsza, ani nie uszkadza. Niewolnik pozostanie wiernym, jeżeli niczego nie straci z dóbr otrzymanych od swego pana”. Ojcowie Kościoła przy okazji objaśniania chrześcijańskiej pragmatyki współżycia małżeńskiego starali się podkreślać, że $\mathrm{w}$ tej materii życia rodzinnego istnieje dysonans pomiędzy normami prawa cywilnego i pragmatyką chrześcijańską. Widząc liberalizm norm prawa cywilnego, ustawiali te normy na dalszym planie. Oto dwa małe przykłady: Origenes, Contra Celsum V 37, SCh 147, 110-112, tłum. S. Kalinkowski: Orygenes, Przeciwko Celsusowi, Warszawa 1986, 270: „Istnieją dwa rodzaje praw: prawo natury, którego twórcą jest Bóg i spisane prawo państwowe. Dobrze, gdy prawo spisane nie sprzeciwia się 
Wprawdzie nauczanie Ojców Kościoła idzie w kierunku powstrzymywania wiernych przed zawieraniem małżeństw z niechrześcijanami ${ }^{18}$, to normy kanonów soborowych i synodalnych coraz mniej pozostawiają niedomówień: ożenek z niewierzącym nie jest dozwolony i Kościół ogłaszał jednoznaczny jego zakaz (interdictum). Oto najważniejsze $\mathrm{z}$ kanonicznych zakazów $^{19} \mathrm{za}-$ wierania małżeństw mieszanych, jakie uchwalono do, i w czasie kapłańskiej służby Jana Chryzostoma:

Synod w Elwirze (Hiszpania, ok. 300 r.):

Kan. 15: „Nie wolno wydawać dziewic chrześcijańskich za pogan [tylko dlatego], aby w kwiecie wieku nie popadły w duchowe cudzołóstwo"20.

Kan. 16: „Heretykom, którzy nie chcą przejść do Kościoła katolickiego, nie wolno dawać za żony dziewcząt chrześcijańskich; ani Żydom, ani heretykom, gdyż nie może mieć nic wspólnego wierny z niewiernym. Gdyby rodzice postąpili wbrew temu, należy pozbawić ich komunii na pięć lat”21.

Kan. 17: „Tym, którzy wydaliby córki za kapłanów pogańskich, nawet na koniec [życia] nie należy udzielać komunii”22.

Kan. 44: „Była nierządnica, jeżeli później wyjdzie za mąż, a następnie przystąpi do wiary, niech będzie przyjęta bez zwłoki”"23.

Synod w Arles (Galia, 314 r.):

prawu Bożemu i nie niepokoi obywateli pozorem dziwnych przepisów; gdy jednak prawo natury, to znaczy prawo Boże, nakazuje coś innego niż prawo spisane, zastanów się, czy rozsądek nie poleca porzucić prawa spisanego i wzgardziwszy wolą ludzkich prawodawców powierzyć się BoguPrawodawcy i układać życie według Jego nauki”; Gregorius Nazianzenus, Oratio 37, 8, SCh 318, 286: „Pierwszy związek jest wedle prawa, drugi za pozwoleniem, trzeci już narusza prawo, a dalej wpada się w obyczaje zwierzęce. [...] Prawo państwowe pozwala na oddalenie żony z jakiejkolwiek przyczyny, podczas gdy prawo Boże zezwala jedynie na takie postępowanie gdy zachodzi przypadek cudzołóstwa; przyzwalając na to usuwa się cudzołożnicę, aby nie wprowadzała bękartów do grona spadkobierców”. Podobną ocenę prawa cywilnego daje w Epistola 144, PG 37, 248: „Rozwód jest sprzeczny z naszymi prawami, choćby rzymskie inaczej rozstrzygało".

${ }^{18} \mathrm{~W}$ polskiej literaturze mamy na ten temat wyczerpujące studium ks. E. Przekopa: Przeszkoda różności religii w kościele bizantyjskim, PK 14 (1971) z. 3-4, 33-67, spec. 48-62 (Przeszkoda różności religii w prawie kanonicznym).

${ }^{19}$ Podaję za: Synodi et collectiones legum (= SCL), t. 1: Acta synodalia ab anno 50 ad annum 381, red. A. Baron - H. Pietras, Kraków 2006 (=ŹMT 37).

${ }^{20}$ Tamże, s. 52.

${ }^{21}$ Tamże.

${ }^{22}$ Tamże.

${ }^{23}$ Tamże, s. 56. 
Kan. 11: „W sprawie dziewcząt chrześcijańskich, które wychodzą za pogan, postanowiono, że na jakiś czas mają być odsunięte od komunii [Kościoła]"24.

Sobór w Nicei (325 r.):

Zapisane u Mansiego kanony: 53, 67 i 68, które zakazują małżeństw mieszanych, uznano za apokryfy ${ }^{25}$.

Synod w Laodycei (Frygia, pomiędzy 347-381 r.):

Kan. 10: „Nie powinni (non oportere) ci, którzy są osobami duchownymi, zezwalać swoim dzieciom na małżeństwa z heretykami”26.

Kan. 31: „Nie należy zawierać związków małżeńskich z żadnymi heretykami, ani oddawać im w małżeństwo swoich synów i córki, ale raczej przyjmować, jeśli przyrzekną, że zostaną chrześcijanami” ${ }^{27}$.

Synod w Hipponie (Afryka, 393 r.):

Kan. 12: „Dzieci osób duchownych (filii episcoporum vel quorumlibet clericos) nie mogą zawierać małżeństw z poganami, heretykami i schizmatykami (cum gentilibus vel haereticis et schismaticis) ${ }^{28}$.

Przytoczone kanony mają wedle większości komentatorów walor zrywający małżeństwo ${ }^{29}$. Nie jest to jednak powszechnie przyjmowana wykładnia prawa kanonicznego z IV wieku, gdyż przeważa pogląd, wspierany nauczaniem łacińskich Ojców Kościoła, że ocena związków mieszanych zawierała jedynie stwierdzenie o ich ,niestosowności”. Wyraźnym jest także ostrzejsze wypowiadanie się Ojców Soborowych, niż Ojców Kościoła, chociaż zwrot kategoryczny „,non licere” w odniesieniu do takich małżeństw, pojawi się dopiero w 72 kanonie synodu w Trullo $(691 \text { r.) })^{30}$. Natomiast bardzo wcześnie w chrześcijańskiej politei za niedopuszczalne małżeństwo uznano ożenek

\footnotetext{
${ }^{24}$ Tamże, s. 72.
}

25 Rangę postanowień soboru powszechnego regulacje małżeństw z nie-chrześcijanami uzyskają dopiero w Chalcedonie (451 r.), por. can. 14, Mansi VII 388, thum. E. Przekop, s. 53. „Ponieważ w niektórych prowincjach pozwala sie lektorom i kantorom pojmować żony, Święty Synod postanowił, że żadnemu z nich nie godzi się brać żony z obcej sekty. Ci zaś, którzy w takim związku zrodzili już potomstwo i jeśli już ochrzcili swoje dzieci u heretyków, wypada aby oddali je wspólnocie Kościoła katolickiego; nie ochrzczone natomiast dotąd nie mogą otrzymywać chrztu z rąk heretyków. Zaręczona podobnie nie powinna łączyć się z heretykiem, Żydem lub poganinem, chyba że zobowiązuje sie doprowadzić osobę prawnie zaręczoną do prawdziwej wiary. Jeśliby zaś ktoś odważył się przekroczyć postanowienie Świętego Synodu, ściągnie na siebie karę kanoniczną".

${ }^{26}$ Concilium Laodicenum can. 10, Hefele-Leclercq I 2, 1002.

${ }^{27}$ Tamże can. 31, Hefele-Leclercq I 2, 1016.

${ }^{28}$ Concilium Hipponensem can. 12, CCL 149, 37.

${ }^{29}$ Por. Przekop, Przeszkoda różności religii, s. 53-54, przyp. 94-97.

${ }^{30}$ Por. Concilium Trullense can. 72, Mansi XI 975: „Non licere virum orthodoxum cum muliere haeretica coniugi neque vero orthodoxam cum viro haeretico copulari”. 
z Żydami. W tej ostatniej kwestii istotną jest paralelność orzeczeń prawa cywilnego i prawa kanonicznego ${ }^{31}$.

Poznawszy Chryzostomowe objaśnienia 1Kor 7, 12-16 nabieram przekonania, że Antiocheńczyk nie rekomenduje swoim słuchaczom korzystania $\mathrm{z}$ privilegium Paulinum, w chwili decydowania o losie partnera (-rki). Przy czym konieczne jest jedno zastrzeżenie, które w pewnym stopniu ogranicza liberalizm Chryzostoma: komentując I List do Koryntian, jasno zaznaczył:

„Powyższe uwagi [Apostol] odnosi do zawartych małżeństw, a nie do planowanych związków małżeńskich. Nie powiedział: «Jeżeli ktoś zamierza zawrzeć małżeństwo z niewierzącym», ale: «jeśli ktoś ma niewierną», to znaczy, jeżeli po ożenku lub zamążpójściu, jedna ze stron przyjmie prawdziwą

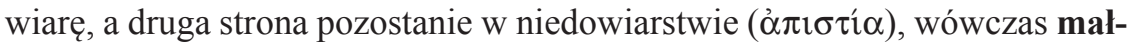
żeństwo nie ulega rozwiązaniu" ${ }^{32}$.

Łącząc w całość, powyższe zastrzeżenie (nie usuwaj niewierzącej osoby z „małżeństwa mieszanego”) i zakaz poślubiania osoby niewierzącej, należy przyjąć, że Chryzostom apostolskie zalecenie: ,niech pozostanie w związku”, odnosi tylko do małżeństw, które niegdyś zawarto w rycie pogańskim. Po jakimś czasie, za sprawą przyjęcia chrześcijaństwa przez jedną ze stron, związek stawał się tzw. „,małżeństwem mieszanym”. W interesie Kościoła było, aby przetrwały związki, które znalazły się w połowie drogi do wspólnoty chrześcijańskich rodzin; w połowie, jako że na razie uwierzył tylko jeden ze współmałżonków. Pożycie małżeńskie partnerów nierównych sobie pod względem religijnym, dawało wielką, a przy tym realną okazję nawrócenia niewierzącego na prawdziwą wiarę. Nie wolno więc, pisał Chryzostom, w chwilach

${ }^{31}$ Najwcześniejszą była decyzja cesarza Konstancjusza z 339 r., którą objęto wybrany krąg kobiet, por. CTh IX 7, 5: „Kobiety, zatrudnione dawniej w cesarskich warsztatach tkackich, a które zostały wciągnięte w haniebne związki z Żydami, niech powrócą do swojej pracy w tychże warsztatach. Należy nadmienić, że w przyszłości Żydom nie wolno wiązać się z chrześcijankami; jeśli to uczynią, będą podlegać karze śmierci”. Najwcześniejsza, obowiązująca wszystkich obywateli, była ustawa z 388 r. podpisana przez trzech cesarzy: Walentyniana I , Teodozjusza I, oraz Arkadiusza, por. CTh IX 7, 5: „Żaden Żyd nie otrzyma chrześcijanki za żonę, jak i żaden chrześcijanin niech nie wchodzi w związek małżeński z Żydówką. A jeśli ktoś popełni ten karygodny czyn, będzie to rozpatrywane na równi ze zbrodnią cudzołóstwa. Wolność wnoszenia oskarżenia gwarantujemy wszystkim ludziom".

32 In Epistolam I ad Corinthios hom. 19, 3, PG 61, 155. We wcześniejszych o kilka lat objaśnieniach do Księgi Rodzaju i Księgi Izajasza nie podkreślał, że nie wolno planować ożenku z niewierzącą. Tam jedynie przypominał, że Apostoł ,nie zabrania niewierzącemu i niewierzącej

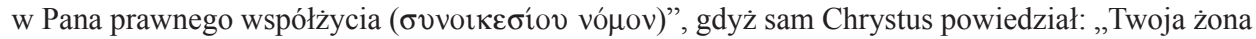
może być poganką lub niewierzącą; skoro tylko chce żyć z tobą, nie odłączaj się", por. In Genesin hom. 26, 2, PG 53, 232. Podobnie w komentarzu do Księgi Izajasza: „Żonę cudzołożną pozwolił oddalić, a żyjącą wedle hellenistycznych obyczajów ('E $\lambda \lambda \eta v i ́ \delta \alpha)$ - nie pozwolił [oddalić], chociaż ta ostatnia zawiniła przeciwko Niemu samemu, a ta pierwsza przeciwko człowiekowi”, zob. In Isaiam hom. 3, 48, PG 56, 48. 
małżeńskiego kryzysu zasłaniać się apostolskim przyzwoleniem na rozwód. Objęcie niewierzącego ochroną, wynikającą z chrześcijańskiej zasady nienaruszalności związku małżeńskiego, jest przejawem głębokiego humanitaryzmu kapłana z Antiochii. Ponadto jest cennym dowodem przemiany prawa małżeńskiego w obszarze chrześcijańskiej politei. Przecież Jan Chryzostom w tym nauczaniu nic innego nie polecał, jak tylko zachowanie małżeństwa, niezależnie od wyznawanej religii jednego z partnerów.

Dobro „najszlachetniejszej politei”, jak zwykł Chryzostom mawiać o chrześcijańskiej wspólnocie, jest celem, któremu należy podporządkować nasze życie, także i to dzielone pomiędzy sprawy małżonków. Takie zachowanie wierzącego wobec jeszcze „nieczystego” wynika z istoty chrześcijaństwa, jak to napisał objaśniając Dzieje Apostolskie ${ }^{33}$. Natomiast słowa z Listu do Hebrajczyków: „Starajcie się o pokój ze wszystkimi i o uświęcenie, bez którego nikt nie zobaczy Pana. Baczcie, aby nikt nie pozbawił się łaski Bożej” (Hbr 12, 14-15), objaśniał jako obowiązujący wszystkich chrześcijan nakaz zjednywania dla Kościoła ludzi obcej wiary. Słowa autora Listu do Hebrajczyków:

„są skierowane do podróżujących, przemierzających w dużej gromadzie bezkresne szlaki. Uważajcie, aby nikt się nie odłączył! Paweł pragnie bowiem nie tylko tego, abyśmy sami cel osiągnęli, ale także i tego, abyśmy się troszczyli o innych - aby nikt nie pozbawił się łaski Bożej. Łaską Bożą nazywa dobra doczesne, wiarę Ewangelii i najszlachetniejszą politeję (óó́ $\sigma \tau \varepsilon v ~ \pi 0 \lambda \imath \tau \varepsilon i ́ \alpha v)$ wszystko to jest łaską Bożą. Nie mów więc lekceważąco: tylko jeden zginął. Za tego jednego umarł Chrystus" ${ }^{\text {"34. }}$

Swoista ochrona niewierzącego współmałżonka, to zarazem podkreślenie roli małżeństwa, które w sytuacji spotkania się wierzącej z niewierzącym ma być przedsionkiem do chrześcijańskiej politei. Chryzostom przypomina:

„Małżeństwo zawieramy, aby je powierzyć Bogu. Nie kierujemy się w takiej chwili chęcią zdobycia majątku, ale pozyskaniem przychylności szlachetnej duszy; nie pożądamy pieniędzy i godności przodków, ale dobroczynności i łagodności obyczajów żony. Powinniśmy wiązać się z towarzyszką życia, a nie z kobietą do zabaw" ${ }^{\prime 35}$.

Także i z tego powodu nie zajmują go radości i kłopoty chrześcijańskiej rodzi-

${ }^{33}$ Por. In Acta Apostolorum hom. 20, 4, PG 60, 162: „Nie zaniechajmy żadnych starań, które mogą wielu doprowadzić do zbawienia [...]. Pamiętajmy, że to jest cel chrześcijaństwa. Dla chrześcijanina nie ma nic bardziej obcego, niż brak troski o zbawienie innych. Nie wolno tobie usprawiedliwiać się brakiem środków [...], pochodzeniem z niskiego rodu [...], brakiem wykształcenia [...], swoimi dolegliwościami [...]. Nie może być ukryte światło chrześcijanina; nie może się ukryć tak jasne źródło światła".

${ }^{34}$ In Epistolam ad Hebraeos hom. 31, 1, PG 63, 213.

${ }^{35}$ In Kalendas 5, PG 48, 960. 
ny, ale chce mówić o przydatności „mieszanych małżeństw” w akcji na rzecz krzewienia chrześcijaństwa.

Jan Chryzostom jest przekonany, i tego naucza, że niewierzący ( $\alpha ́ \pi \imath \sigma$ -

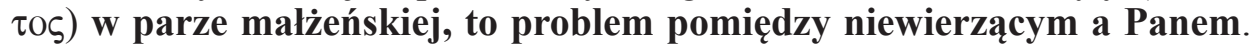
Głosząc tę zasadę, ułatwiał niejednemu wiernemu podjęcie decyzji, jako że zdejmował z nich ciężar odpowiedzialności za los ciągle jeszcze niewierzącego partnera. „Twego partnera relacje z Panem”, niezmiennie przypomina Chryzostom, „nie powinny decydować o trwaniu lub zerwaniu związku małżeńskiego". Kierując się prywatą, chcąc zmienić partnera (-rkę), stajemy na pozycji surowego sędziego i wykrzykując: ,jako chrześcijanin nie mogę współżyć z poganką", wyrzucamy poślubioną kobietę ze swojego domu. Takie zachowania Jan Chryzostom negliżuje i usuwa poza krąg chrześcijańskiej politei. Jego pouczenia kierowane do małżeństw osób różnych religii, można sprowadzić do prostej zasady: nie wykorzystuj do własnych celów relacji, jakie twój bliźni ma z Panem. Chrześcijański partner często uzasadniania rozwód obawą, że współżycie z poganką (-ninem) zagraża jego (jej) zbawieniu. Takie tłumaczenie, nie raz konkluduje Chryzostom, jest przejawem niegodnej dewocji i skrywanej pod nią hipokryzji.

Współmałżonka (-nkę), jeżeli dopuścił (-ła) się zdrady małżeńskiej, można ukarać separacją, gdyż takim aktem skrzywdził (-ła) swego bliźniego. Jednak akt cudzołóstwa nie jest zdradą Pana. Swojego Pana zdradzasz wtedy, zdaje się pouczać ten kapłan, jeżeli pozostawisz współmałżonka poza kręgiem wierzących. Niewierzący ze swojej natury jest winnym wobec Pana, więc tego przewinienia nie może ścigać drugi człowiek. Chrześcijanin nie może szukać okazji, aby swego partnera wypędzić ze wspólnoty wiernych. Stąd też w homiliach Jana Chryzostoma słyszymy: „Nie wolno być sędzią w sprawach pomiędzy Panem i współmałżonkiem”. Mocny tego dowód znajdujemy w Komentarzu do Księgi Rodzaju, gdzie (XXVI homilia) gromadząc świadectwa Bożej filantropii przywołał przypadek Kaina, któremu wybaczono grzechy wobec Boga, ale surowo ukarano za przestępstwo wobec bliźniego. W tym wydarzeniu znalazł punkt odniesienia do sformułowania zasady: „grzechy wobec Boga pozostaw Bogu”, którą radzi stosować także w praktyce życia małżeńskiego.

„Bogu należy pozostawić nasze grzechy uczynione przeciwko Niemu, a za grzechy popełnione przeciwko naszemu bliźniemu surowo karać. Posłuchaj co mówi Paweł (1Kor 7, 12-13). Czy dostrzegłeś, jaką okazał powściągliwość? Jeżeli twój mąż, choć Hellen i niewierzący, pragnie żyć razem z tobą, to nie odtrącaj jego. Podobnie, mówi Apostoł, sprawa się ma z żoną poganką i niewierzącą ( $(\alpha \pi \imath \sigma \tau o \varsigma)$; jeżeli pragnie żyć z tobą, to nie odtrącaj jej. «A skądże zresztą możesz wiedzieć, żono, że zbawisz twego męża? Albo czy jesteś pewien, mężu, że zbawisz twoją żonę?» (1Kor 7, 16). Zapamiętaj, [Apostoł] nie zabrania niewierzącemu i niewierzącej w Pana prawnego współżycia 
( uczniom: «Powiadam wam: każdy, kto oddala swoją żonę - poza wypadkiem nierządu - naraża ją na cudzołóstwo» (Mt 5, 32). Cóż za umiłowanie człowieka! Twoja żona, powiedział, może być poganką lub niewierzącą; skoro tylko chce żyć z tobą, nie odłączaj się. Gdyby jednak zgrzeszyła przeciwko tobie i zapominając o małżeńskich nakazach okazała względy innym, wtedy wolno ci odłączyć się od niej i ja oddalić"36.

Jan umacnia „ochronę” niewiernego w małżeńskim zaprzęgu, wprowadzając dodatkowy nakaz - motyw chrześcijańskiej jałmużny. Niewierzący, nauczał Chryzostom, zasługuje, aby obdarzyć go małżeńskim zaufaniem, tak jak zasługuje, aby dać mu jałmużnę. Ucząc Ewangelii, wierny wspomaga niedowiarka w sposób podobny do jałmużny danej biednemu. Co więcej, troska o niewiernego jest udzieleniem pomocy grzesznikowi, a to sprawia, że taka jałmużna jest aktem najczystszej prawdy o chrześcijaństwie. W przejmujący sposób tę prawdę ukazał komentując List do Hebrajczyków:

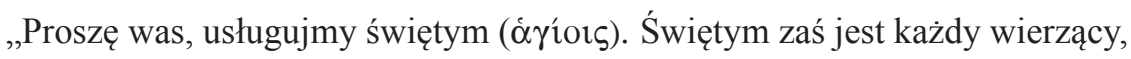

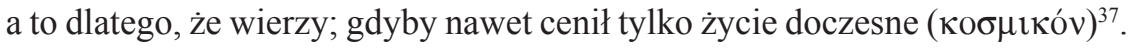
«Uświęca się», mówi apostoł, «niewierzący mąż». Widzisz wiec, że wiara sprowadza uświęcenie. Widząc nieczystego światowca, podajmy mu pomocną rękę. Nie troszczmy się tylko o tych, którzy mieszkają w górach ${ }^{38}$. Oczywiście, z racji sposobu życia i wiary, wszyscy oni są święci [...]. Jednak podajmy rękę także światowcowi; on jest naszym bratem i także jest świętym. No dobrze, zawołasz, ale jeśli jest nieczysty i skalany? Pamiętasz co powiedział Chrystus: «Nie sądźcie, abyście nie byli sądzeni» (Mt 7, 1). Dobroczynnym należy być także wobec nieczystego Hellena i wobec każdego innego człowieka, który znalazł sie w stanie nieczystym A co mówił Paweł: «czyńmy dobrze wszystkim, a zwłaszcza naszym braciom w wierze» (Ga 6, 10). Nie rozumiem, skąd się u nas wziął [odmienny] obyczaj i jakim sposobem się rozpowszechnił. Przecież zatraca istotę jałmużny ten, kto godnych podania ręki wynajduje tylko wśród żyjących wedle obyczaju mnichów

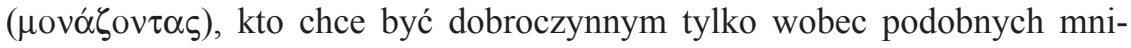

${ }^{36}$ In Genesim hom. 26, 2, PG 53, 231-232. Podobnie brzmią jego słowa w Komentarzu do Księgi Izajasza, por. In Isaiam hom. 3, 48; PG 56, 48: „Bóg zawsze bardzo się troszczy o tych, których skrzywdzono; troszczy się nie mniej niż o tych, którzy zgrzeszyli przeciwko Niemu, a niekiedy bardziej gniewa się za grzechy przeciwko podobnym nam niewolnikom. Żonę cudzołożną pozwolił oddalić, a żyjącą wedle hellenistycznych obyczajów - nie pozwolił [oddalić], chociaż ta ostatnie zawiniła przeciwko Niemu samemu, a ta pierwsza przeciwko człowiekowi".

${ }^{37}$ Dosłownie był ,światowcem”.

${ }^{38}$ Mnisi w swoich pustelniach, rozrzuconych na wzgórzach otaczających Antiochię, por. J. Iluk, Jana Chryzostoma „XVII homilia o posagach”, w: Księga Jubileuszowa ofiarowana Profesorowi Waldemarowi Ceranowi, red. M. Kokoszko - M.J. Leszka, Byzantina Lodziensia XI, Łódź 2007, 187-198. 
chom, kto usiłuje wśród nich odnaleźć lepszych, wskazać podlejszych, mniej prawych i nie czyniących znaków. Zapomina, że prawdziwą jałmużną jest obdarowywanie grzesznych lub winnych. Miłosierdzie polega bowiem na tym, że miłujemy nie tych, którzy są bez zarzutu, ale tych, którzy zgrzeszyli [...]. Jeżeli ratując zdychającego osła, nie pytasz kto jest jego właścicielem, to nie pytaj człowieka: do kogo należysz? Każdy przynależy do Boga, nawet jeśli to Hellen, nawet jeśli to Żyd, a pomocy oczekuje także niewierzący"39.

Uzasadniając konieczność otoczenia opieką niechrześcijańskiego współmałżonka, Jan Chryzostom znajduje także okazję, aby podkreślić znaczącą rolę żony - „nauczycielki chrześcijańskiego życia”. Ta rola niezbyt pasuje do miejsca, jakie św. Paweł wyznaczył kobiecie w 1Tm 2, 12: „Nauczać zaś kobiecie nie pozwalam, ani też przewodzić nad mężem lecz chcę, by trwała w cichości". Dostrzegając ten dysonans, nasz kapłan zwraca uwagę na predyspozycje partnerki:

„Powrócę do wątku o kobietach, abyś zobaczył jak Błogosławiony Paweł nakłada (1Tm 2, 12) i zdejmuje z nich nakaz podporządkowania się mężowi (1Kor 7, 16), wprowadzając je znów na katedrę nauczyciela ( $\delta 1 \delta \alpha \sigma \kappa \alpha \lambda i ́$ is $\theta \rho o ́ v o v)$ [...]. Zapytasz: W jaki sposób żona może męża zbawić? Ucząc go, zapoznając z religią ( $\alpha \tau \eta \chi 0 \hat{\sigma} \sigma)$, wyjaśniając zasady bogobojności [...]. Niech więc żona wierząca uczy męża niewierzącego. Dlaczego? Dlatego, że nie kieruje się pokusami, ale jest wierną, a mąż, jako niewierzący, ulega pokusom"40.

Dylemat: pozwolić czy zakazać kobiecie-mężatce nauczania mężczyzn, powraca w objaśnieniach słów Apostoła: „Pozdrówcie współpracowników moich w Chrystusie Jezusie, Pryskę i Akwilę" (Rz 16, 3):

„W jaki sposób wierząca żona może uratować męża? Przede wszystkim

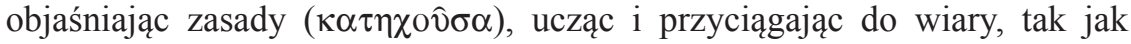
Priska Apollosa. Poza tym, kiedy [Paweł] mówi: «kobiecie nie pozwalam

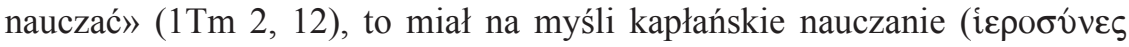
$\lambda$ ófov) i dyskusję na publicznym zebraniư ${ }^{41}$.

Tym razem ów dylemat rozwiązuje się po stwierdzeniu, że w I Liście św. Pawła do Tymoteusza zakaz ów dotyczył małżeństw, w których mąż był także

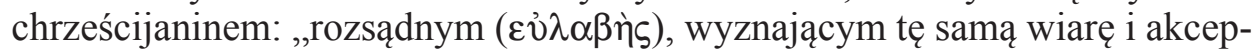

${ }^{39}$ In Epistolam ad Hebraeos hom. 10, 4, PG 63, 87-88. O konieczności modlitwy za niewiernych przekonuje komentując I List św. Pawła do Tymoteusza, por. In Epistolam I ad Timotheum hom. 6, 3, PG 62, 533: „Gdyby modlitwa: «Niech Twoja wola spełnia się na ziemi, tak jak i w niebie» (Mt 6,10) obejmowała tylko tych, którzy są wierzący, to te słowa nie miałyby sensu, ponieważ gdyby tylko wierzący mieli spełniać Jego wolę, a niewiernych to nie dotyczyłoby, to oznaczałoby, że Jego wola na ziemi - gdzie pełno niewierzących, nie spełnia się tak, jak w niebie, gdzie są tylko wierzący”.

${ }^{40}$ In Genesim hom. 5, 1, PG 54, 600.

${ }^{41}$ In illud: ,, Salutate Priscillam et Aquilam” 1, 3, PG 51, 192. 
tującym te same wartości”42. Jeśli natomiast jest niewierzącym i błądzącym, wówczas Apostoł nie odbiera jego małżonce prawa do pouczania go, oświadcza Jan Chryzostom.

Wypowiedzi na temat niewierzącego małżonka odsłaniają istotną cechę Chryzostomowego myślenia o sposobach krzewienia religii. W tym myśleniu szczególne miejsce znalazły małżeństwa mieszane. W chrześcijańskiej politei jawią się one oazą, w której osoby innej religii odnajdują prawdę Ewangelii. Tworzenie tych oaz, nauczał Chryzostom, a nie korzystanie z ,przywileju Pawłowego", jest miarą chrześcijańskiej godności ( $\alpha \xi \hat{\xi} \alpha)$; to przecież pozyskiwanie obcych - tych z obrzezanych i tych z pogan, zapoczątkowało niegdyś ziemską historię ,najszlachetniejszej politei”. „Nie rozrywaj małżeństwa”, nauczał Chryzostom w antiocheńskim Kościele, gdyż:

„Pierwszą zasadą jest sławić Boga wśród innych [... Jeśli jesteśmy światłem, zaczynem i solą, to powinniśmy promieniować, a nie pozostawać w mroku; umacniać, a nie osłabiać; przyciągać do siebie niewiernych, a nie odganiać ich od siebie. Dlaczego odganiasz tych, których powinieneś przyciągać? Rzeczywiście, naszym zatroskaniem o innych upokarzamy Hellenów; tego samego uczucia doznają Żydzi i słabi spośród naszych braci. Wszyscy oni nie znają naszych idei i nie wiedzą, że nie ma zniewagi, która mogłaby dotknąć naszą duszę"

${ }^{42}$ In illud: ,Salutate Priscillam et Aquilam” 1, 3, PG 51, 192.

${ }^{43}$ In Epistolam I ad Corinthios hom. 25, 2, PG 61, 208. Podobnie w innym miejscu (In Genesin hom. 8, 5, PG 53, 73-74): „Bogu jest miłe, jeżeli chrześcijanin troszczy się nie tylko o siebie, ale także kształtuje innych, ucząc ich dając przykłady ze swojego życia i obyczajów. Nie ma lepszego sposobu sprowadzenia na drogę prawdy, jak dołączenie do uporządkowanej politei ( $\pi \circ \lambda \iota \tau \varepsilon i ́ \alpha \varsigma$

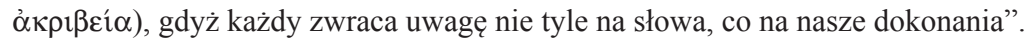




\section{APISTIA DOES NOT TEAR MARRIAGES APART JOHN CHRYSOSTOM ON SPOUSES FROM OUTSIDE THE CHRISTIAN POLITEIA}

\section{(Summary)}

Apart from a few treatises on the life of women in an extra-marital state and some short speeches about the dignity of Christian women, John Chrysostom did not engage in longer discourses about marriage. Chrysostom expressed himself most broadly on this subject in his commentary to "The First Letter to the Corinthians". This and over a dozen other utterances by Chrysostom which I found in his writings allow us to suppose that his assessment of the value of the union between a believer and a non-believer is dictated by the realism of the epoch and not by pure dogma. Such a tone of teaching resonates with the moods of the Antioch community, which seethed with the luxuriant life of the most va-

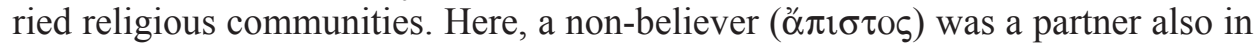
marriage, hence the use of the "Pauline privilege" in order to remove such a one from a marriage would expose Christians to the accusation of a lack of tolerance at the very least.

Knowing his community very well, John Chrysostom brings to the foreground the principle that a non-believer in a married couple is a problem between the nonbeliever and the Lord. Civil law does not make an impediment of this (such was the Roman tradition) and Canon law (the synods of the $4^{\text {th }}$ century) should not make such impediments either. „Your partner's relations with the Lord”, Chrysostom continually reminds us, ,should not decide about the continuation or the dissolution of the marital union". The „defence” of a spouse from outside the Christian politeia is also an opportunity to obtain new members of this community. 
